\title{
APPLYING BENJAMIN BLOOM'S TAXONOMY IDEAS IN ADULT LEARNING
}

\author{
NATALIIA HREBIN \\ Ivan Franko National University of Lviv \\ Faculty of Philosophy, Department of Psychology \\ Universytetska Street 1, Lviv, Ukraine \\ E-mail address: nataliya.hrebin@lnu.edu.ua \\ ORCID number: https://orcid.org/0000-0002-9473-0404 \\ SOFIIA HRABOVSKA \\ Ivan Franko National University of Lviv \\ Faculty of Philosophy, Department of Psychology \\ Universytetska Street 1, Lviv, Ukraine \\ E-mail address: sofiia.hrabovska@lnu.edu.ua \\ ORCID number: https://orcid.org/0000-0003-4256-1191 \\ RUSLANA KARKOVSKA \\ Ivan Franko National University of Lviv \\ Faculty of Philosophy, Department of Psychology \\ Universytetska Street 1, Lviv, Ukraine \\ E-mail address: Ruslana.Karkovska@lnu.edu.ua \\ ORCID number: https://orcid.org/0000-0003-0416-4371 \\ ANNA VOVK \\ Ivan Franko National University of Lviv \\ Faculty of Philosophy, Department of Psychology \\ Universytetska Street 1, Lviv, Ukraine \\ E-mail address: Anna.Vovk@lnu.edu.ua \\ ORCID number: https://orcid.org/0000-0003-1505-7096
}

\begin{abstract}
Aim. The research goal of this paper is to theoretically substantiate the feasibility of using Benjamin Bloom's psychological and pedagogical model and its modifications in the adult learning system.

Methods. The study used the methods of theoretical analysis, synthesis and modelling of the implementation options for Bloom's techniques in the training of adults.
\end{abstract}

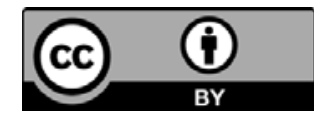


Results and Conclusions. The analysis showed that the use of techniques based on Bloom's taxonomy, modified for adult training, makes it possible to develop students' skills and abilities to thoroughly and comprehensively analyse the problem, and to find creative, effective solutions. Such a sequence of task setting as "reproduction" (knowledge), "understanding" (comprehension), "application," "analysis," "evaluation," and "creation" is proposed as a general scheme of various training for adults. In particular, an example of the design of training in developing communication skills and training in overcoming procrastination skills is given.

Key words: Bloom's taxonomy, Bloom's cube, hierarchy of mental operations, adult learning.

\section{INTRODUCTION}

A dult education is a key component of lifelong learning that encompasses all forms of education and training aimed at providing opportunities for adults to participate in the life of their communities and in the field of work. By adult education scientists understand "a complex of continuous learning processes - both formal and the whole range of its informal forms and types, with the help of which adults develop their abilities, enrich their knowledge, improve professional qualifications or apply them in new areas" (Baranovska \& Baranovsky, 2014, p. 14).

Today, lifelong learning is necessary both for a successful professional career and for the optimal solution to life outside work. When teaching adults, it is necessary to take into account the peculiarities of their life experience, their age and socio-psychological qualities. As noted by Larysa Tsvyak, adult learners can independently determine the goals of their educational activities, seek immediate practical application of the knowledge and skills gained, place high demands on the quality and learning outcomes, evaluate and adjust the results of promotion (Tsvyak, 2014).

The ability to absorb new information in an adult decreases with age. Therefore, it is becoming increasingly popular to use a variety of interactive techniques in adult education that facilitate the learning process, make it active, informal, interesting, emotionally attractive and, at the same time, manageable. Adult education cannot be carried out by using traditional forms and teaching methods, which are predominantly intellectually passive. The use of active teaching methods enhances motivation and improves the formation of skills and abilities due to the maximum involvement in the educational process (Baranovska \& Baranovsky, 2014).

Scholars propose building an adult learning system based on behaviour-oriented models that focus on the acquisition of specific skills and competencies that can be practically demonstrated (Harris, 2013). As a model, Benjamin Bloom's pedagogical taxonomy can be applied (Bloom, 1984). B. Bloom's taxonomy is primarily designed to form mental operations in children, but its models inspire to the creation of techniques and methods that can diversify the methodological arsenal of andragogy. The purpose of the study is to theoreti- 
cally substantiate the feasibility of using B. Bloom's psychological and pedagogical model and its modifications in the adult learning system.

\section{ANALYSIS OF THE LATEST STUDIES AND PUBLICATIONS}

The term "taxonomy" (from the Greek words taxis - order, and nomos method) can be translated as a law, an arrangement in a certain order which is borrowed from biology. Arrangement by a certain criterion allows classifying the ordered. To develop effective methods for the formation of mental operations, the idea of ordering is important not only for classifying these operations and skills but also primarily for determining the sequence of their formation both in ontogenesis and in solving specific problems. In the context of adults, mental operations should 'work' at the level of skills. However, firstly, not in all adults the logical forms and mechanisms have been mastered in a timely and thorough way, and secondly, the solution to each specific problem can be facilitated if the thinking process of the person solving it is logically ordered and expediently organised. B. Bloom proposed the concept of pedagogical taxonomy, which means building a clear system of pedagogical goals, in which the corresponding criteria and the sequence of levels are established (Podopryhora, 2016). B. Bloom's hierarchy covers three main areas of learners' activity: cognitive, affective and psychomotor. Educational objectives in the cognitive area are aimed at developing thinking and gaining knowledge, the impact on the affective area involves increasing one's learning motivation, self-esteem, and the formation of values. The psychomotor area plays a leading role in the development of motor skills, physical endurance, etc. (Bloom \& Krathwohl, 1956; Harrow, 1972).

Educational objectives reflect not only the levels of information awareness but also the intellectual operations through which the learning information is transferred to the system of cognitive structures (Sverdlova, 2015).

The cognitive domain of B. Bloom's taxonomy consists of 6 levels of cognitive activity, ranging from simple to more complex: Knowledge - Comprehension - Application - Analysis - Synthesis - Evaluation. It is advisable to formulate educational objectives according to each level of cognitive activity.

The level of knowledge implies the development of educational objectives aimed at memorising, recognising and reproducing the basic elements of educational information. The level of understanding involves the ability to interpret the material and to transfer the acquired knowledge to a similar problem-based situation. The level of application implies the students' ability to use knowledge in practice. The levels of analysis and synthesis are about the ability to analyse and systematise elements, establish relationships between them, and synthesise ideas. The level of evaluation provides for the development of diagnostic skills and critical thinking (Bloom \& Krathwohl, 1956).

Lorin Anderson and David Krathwohl revised and developed B. Bloom's ideas, and presented knowledge divided into four levels: factual, conceptual, 
procedural and metacognitive (Anderson \& Krathwohl, 2001). This division of mental operations describes the structure of cognitive activity: "knowledge $\rightarrow$ understanding $\rightarrow$ application." Such a process of forming skills and abilities is related not only to physical but also to mental actions. When skills are developed, a person automatically uses basic mental actions; he/she can analyse, evaluate and create something new. D. Krathwohl introduced a two-dimensional taxonomy model, where one dimension reflects the learning outcomes (the knowledge dimension, factual, conceptual, procedural, metacognitive) and the second dimension indicates the cognitive process dimension (remember, understand, apply, analyse, evaluate, create) (Krathwohl, 2002).

According to the updated taxonomy, each level of knowledge can be correlated with each level of the cognitive process so that an individual can remember factual or procedural knowledge, understand conceptual or metacognitive knowledge, or analyse metacognitive or factual knowledge (Samoylenko \& Ivashchenko, 2017).

Many scientists have been modifying B. Bloom's classic taxonomy, trying to adapt it to the realities of modern education. In 2003, Dee Fink presented a taxonomy, which has no hierarchical structure but instead is based on interaction. His model contains a triad consisting of learning goals, the activities of those involved in the teaching and learning process, as well as feedback and assessment (Fink, 2003). Based on L. D. Fink's ideas, learning types are focused on acquiring Foundational Knowledge (Understand and remember), Application (Critical, creative and practical thinking), Integration (Make connections among ideas, subjects, people), Human Dimensions (Learning About and changing one's self; understanding and interacting with others), Caring (Identifying, changing one's feelings, interests, values), Learning to learn (Learning how to ask and answer questions) (O'Neill \& Murphy, 2010).

Another alternative to B. Bloom's taxonomy, often used in higher education, is the SOLO Taxonomy (Structure of the Observed Learning Outcome) (Biggs \& Collis, 1982; Biggs, 1999). There are five hierarchical levels: Pre-structural - when there is lack of knowledge on a specific issue; Uni-structural when one particular aspect of the problem becomes clear; Multi-structural when several elements are understood, but it is still difficult to relate them to one another; Relational - when a more or less clear structure can be built from various elements of knowledge; Extended Abstract - when knowledge can be generalised and transferred to another area. SOLO focuses more on cognitive processes than on learning outcomes (O'Neill \& Murphy, 2010).

Andrew Churches (2008) introduced a 'digital' taxonomy for schoolchildren and students of the $21^{\text {st }}$ century. He revised the key verbs that represent cognitive goals and put forward innovative terms along with traditional ones.

Since digital technology has become an integral part of education and other areas of life, the modification introduced by A. Churches allows extending the potential of B. Bloom's pedagogical taxonomy by bringing it closer to the modern realities of human life. 
Modified versions of B. Bloom's taxonomy developed by Robert Marzano (2000) and Allan Carrington (2015) are quite popular. Based on the taxonomy, training courses are designed for students and adults within the lifelong education system. Georgia L. Harris (2013) points out that when using B. Bloom's taxonomy, cognitive levels can be compared with teaching and assessment methods. In particular, at the taxonomic level of "Knowledge," the method of lecture, demonstration of various videos and the like can be applied. At the level of "Comprehension," it is advisable to organise discussions, ask students questions. It is proposed to use knowledge tests as a method of assessment. At the taxonomic level of "Application," it is advisable to introduce demonstrative practices in training; the level of "Analysis" provides for solving case studies; at the level of "Synthesis," a teacher can introduce simulation exercises; while the high level of "Evaluation" is achieved during the development of projects, and it involves not a mere reproduction of acquired knowledge but the creation of new knowledge. On the basis of the last three levels of cognition, the author provides the following assessment methods: assessment of abstracts, reports, problem-solving and simulation exercises (Harris, 2013).

Thus, the taxonomy method facilitates the memorisation and reproduction of the material studied and involves problem-solving when a learner has to reinterpret the existing knowledge, build new structures and create new knowledge. Below, we investigate interactive practices that are based on B. Bloom's taxonomy and can be applied to adult learning.

The methods proposed by B. Bloom form the basis for many opportunities for developing interactive exercises and techniques ("Bloom's Cube," "Bloom's Daisy," etc.). These models allow bringing the game spirit into the process of studying a certain educational material, at the same time clearly structuring the learners' thinking process. In B. Bloom's Cube model, students are encouraged to study a certain material using the following steps (actions):

- name it - transparently naming a specific subject, phenomenon and formulating a problem (this contributes to the actualisation of certain knowledge);

- answer why? - describing the process, identifying causal relationships;

- explain -arguing a certain, providing arguments confirming or refuting a certain opinion;

- $\quad$ share - articulating the experiences caused by a particular problem or information;

- invent - designing specific strategies for approaching a phenomenon or problem under discussion, defining what tools can be applied;

- $\quad$ suggest - providing one's own hypotheses or ideas for solving the problem, presenting various ways to solve it (Bloom, 1984).

These actions are indicated on the cube faces, so when tossing it, a student might receive a different task each time. Besides, the student knows in advance that there are six actions that he/she has to be able to perform, but which of them is to be carried out right now is randomly selected, depending on the casting of the cube. 
Other mental operations may be an alternative to the tasks offered to adults during training sessions. The following task sets can be used:

- describe, compare, suggest an association, analyse, use, give an assessment;

- imagine, submit an idea, specify, present the main categories, classify, generalise;

- $\quad$ give a definition, pick up the facts, compare the facts, give the opposite opinion, suggest a metaphor, tell where you can apply it.

The list of possible sets of mental operations and actions is not limited to the above. Based on the goal and professional needs, each trainer can create other sets of tasks for the training participants. If necessary, these tasks can be combined in different ways, each time providing a new version of the activities.

The very idea of using the cube to perform certain actions is interesting since it helps to enhance learners' motivation. The unexpectedness and randomness of the actions that are to be carried out strengthen attention, increase the motive of competition, and force both a child and an adult student to be attentive.

The cube can easily be made of paper or cardboard. The unfolding of the cube is shown in Figure 1.

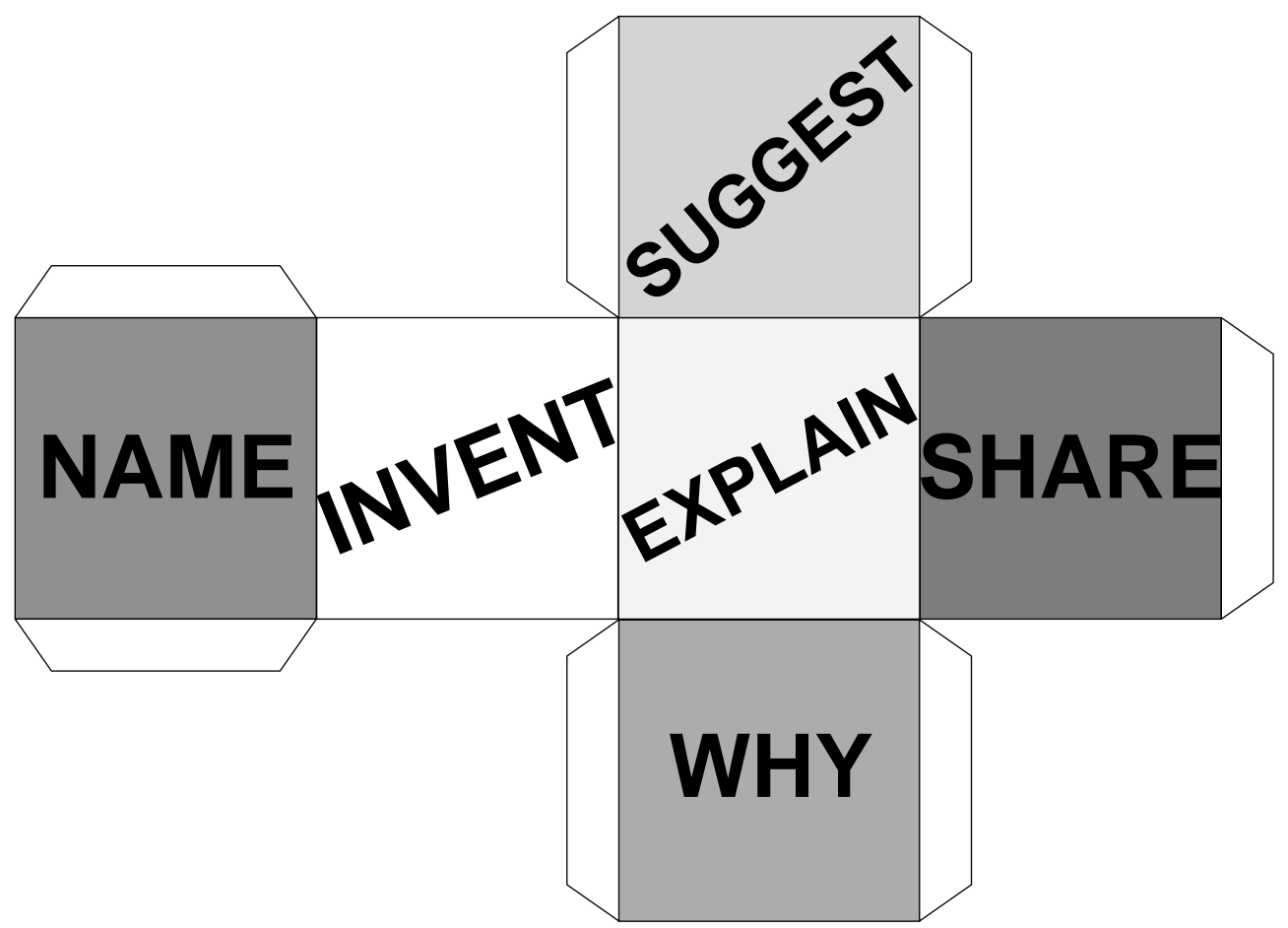

Figure 1. An unfolding the B. Bloom's Cube. Source: Own research.

Let us consider the following option for group work with a specific problem or training material. To perform this technique, a group may consist of 2 to 6 persons. All participants take turns (for example, clockwise) in tossing the cube and performing the function indicated on its top side. Other participants listen carefully to their peer and ask clarifying questions as needed. The discussion goes on 
until all participants have had the opportunity to speak, the tasks indicated on all faces of the cube are completed, and the trainer and group members agree that the material has been learned or the problem has been solved.

Another option of this session is that each member of the group of six has a B. Bloom's Cube with a specific set of actions to be performed. First, the participants in the discussion should receive (or determine) the problem, then they should agree which of the functions indicated on the sides of the cube will be performed by each member of the group, determine the sequence of actions during the session and put their cubes in a row so that the faces indicate the sequence the actions of each participant in the discussion. Next, all group members take turns to play their role in discussing a problem or completing a task.

Working with cubes introduces a certain element of the game and makes mental work less tedious. On the other hand, when the work is organised in such a way, it is often difficult to achieve a logical sequence of actions, which is important in the process of solving a problem or mastering educational material. This limitation can be overcome if the functions presented on the cube are inserted in the table, and in such a way the desired logical sequence of actions is established (see Tables 1-3).

Table 1.

Table of functions for discussion ("B. Bloom's Cube").

\begin{tabular}{c|c|c|c|c|c}
\hline name it & why? & explain & share & invent & suggest \\
\hline & & & & & \\
\hline & & & & & \\
\hline
\end{tabular}

Source: Own research.

Table 2.

Table of functions for discussion (model by L. Anderson and D. Krathwohl).

\begin{tabular}{c|c|c|c|c|c}
\hline knowledge & understanding & application & analysis & assessment & creation \\
\hline & & & & & \\
\hline & & & & & \\
\hline
\end{tabular}

Source: Own research.

Table 3.

Table of functions for discussion (mental operations).

\begin{tabular}{c|c|c|c|c|c}
\hline describe & compare & $\begin{array}{c}\text { suggest an } \\
\text { association }\end{array}$ & analyse & use & $\begin{array}{c}\text { give an } \\
\text { assessment }\end{array}$ \\
\hline & & & & & \\
\hline & & & & & \\
\hline
\end{tabular}

Source: Own research.

Workshop participants can work with such tables individually, or their diverse interaction in groups can be organised. If the individual work with tables is proposed to the workshop participants, the trainer should explain what exactly each participant has to do, and what the specified functions mean. 
The sequence of filling in the columns of the table can be either determined by the participant of the workshop, or suggested by the trainer. To summarise the results of the work, a general table should be compiled and discussed.

Experience shows the convenience and effectiveness of step-by-step work with tables, which can be organised in stages in a group of six (or in a larger group divided into small groups of 6 people):

Stage 1. Each participant receives a specific number (from 1 to 6 ) and the task is to fill in the column of the table corresponding to this number.

Stage 2. Each participant in a small group presents his/her groundwork to the fellow students and fills in the corresponding column of the table. Other participants may ask questions or make suggestions for clarification. Each of the small groups fills in a separate table. Upon completion of the work, each group presents the results of their work, which are compared and generalised by all participants in the workshop during the general discussion.

It may be convenient to use a written problem description for working with certain faces of B. Bloom's cube. After the problem is discussed and identified, the workshop participants should be divided into 6 small groups (with any number of participants). The discussed problem should be in front of the participants throughout the exercise: it should be written on the board or projected on the screen. The trainer must prepare 6 sheets of paper in advance (depending on the volume and complexity of the problem - A-4 or A-3 format), write down or print on the top of each sheet the actions that need to be done, or the mental operations that need to be performed. For example, name, why, explain, share, invent, suggest.

The trainer gives each small group one of the sheets and determines the duration of work on one task (depending on the complexity of the problem, it can be from 2-3 to 10 minutes). Each group discusses the received task and writes down the result on a sheet of paper. When the time is up, the trainer passes the sheets clockwise to other groups, invites them to get acquainted with their peers' results and to add something from their group, without repeating what has already been written or criticising peers who have already written their thoughts on this sheet of paper. Work continues until all 6 sheets are processed sequentially by all groups. The trainer should transfer the sheets from group to group in a circle in one direction to organise the coordinated and smooth work of the groups so that all everyone works with all the tasks. When all the groups have completed all the tasks and left the results of their work on all the sheets, each group receives the sheet they started with. Now, each group has to summarise what has been written, present everyone the result of a certain task, and write it down into the general table.

When organising adult learning, B. Bloom's Daisy model can also be successfully applied. This model is designed to facilitate the children's development of the ability to ask different types of questions, which at the same time allows them to master important mental operations. The daisy has 6 petals -6 types of questions. When a student tears off the petals, he/she has to formulate a specific question. 
Table 4 summarizes the relationship between the questions and the mental operations proposed by B. Bloom in his Daisy model.

Table 4.

Questions according to the "B. Bloom's Daisy" model.

\begin{tabular}{l|l|l}
\hline No. & Mental operation & Question \\
\hline 1 & Reproduction & $\begin{array}{l}\text { A simple question (an answer to which one should recall } \\
\text { and reproduce certain information) }\end{array}$ \\
\hline 2 & Comprehension & $\begin{array}{l}\text { Clarification (a question scrutinising whether certain } \\
\text { information is correctly understood) }\end{array}$ \\
\hline 3 & Application & Practical issues (where and how something can be used) \\
\hline 5 & Analysis & Interpretation (why something has happened) \\
\hline 6 & Eynthesis & Creative questions (how to create, or how to do something) \\
\hline
\end{tabular}

Source: Own research.

This model can help teach children to ask the right questions, and adult participants - to thoroughly and comprehensively analyse problems, and find interesting non-trivial solutions.

Having modified the content of this model, below we describe the technique of organizing work whose aim is to solve a specific problem during a training workshop for adults.

The work consists of several successive stages:

Stage 1: workshop participants should propose the maximum number of different points of view (standpoints) on the problem being discussed, briefly formulate them and write them down on the "petals" of the daisy;

Stage 2: participants should place the standpoints on the "daisy" according to certain criteria (for example, which standpoints are close, compatible; which are mutually exclusive; which can be combined as they overlap each other; in terms of accessibility and complexity of fulfilment; in terms of availability of resources for fulfilment; in terms of the cost of proposed projects, etc.). If there are too many "petals," their number should be reduced by generalising or combining similar proposals. The number of "petals" with ideas left on the "daisy" should correspond to the number of groups an educator plans to have (or to the number of participants, if there are not many participants in the training) in the next stage of work. For effective work, it is enough to have (leave) 5-6 "petals" on the "daisy";

Stage 3: participants are divided into groups and distribute tasks among themselves. If there is a sufficient number of training participants, they can be divided into small groups according to the number of "petals." It is advisable to randomly distribute the "petals" - tasks for each group (participants).

Stage 4: working on the task; 
Stage 5: participants present the results of tasks performed by their groups. The sequence of the presentation of the results is determined by the sequence of "petals" of the "daisy," which was formed at the end of stage 2 of the session.

In general, the ideology of taxonomy itself is useful for designing training. Systemic mentality requires systematic work with its components; and often everything seems equally important, so it is difficult to build a logical chain of actions, exercises that would expediently contribute to the formation of certain skills and abilities, which is the purpose of the training. If we take the following sequence of work stages (steps) - "reproduction" (knowledge), "understanding," "application," "analysis," "evaluation," "creation," - then we can develop very different training in terms of their content.

Below are two examples. The training design for developing skills of the electronics supermarket staff to effectively communicate with customers, developed according to the indicated sequence, may look as follows (see Table 5):

Table 5.

Training design for developing skills of electronics supermarket staff to effectively communicate with customers.

\begin{tabular}{c|c|l}
\hline & Stage & \multicolumn{1}{c}{ Content } \\
\hline 1 & Reproduction & $\begin{array}{l}\text { Sharing knowledge about what 'works' } \\
\text { Mini-lecture “Mechanisms of effective communication" }\end{array}$ \\
\hline 2 & Understanding & $\begin{array}{l}\text { Participants' introspection: what skills and abilities I have } \\
\text { to communicate effectively; what knowledge, skills and } \\
\text { abilities I am lacking }\end{array}$ \\
\hline 3 & Application & $\begin{array}{l}\text { Exercises to develop communication skills. Techniques for } \\
\text { working with different types of buyers. }\end{array}$ \\
\hline 4 & Analysis & Case studies. \\
\hline 5 & Evaluation & Working with videos. Role playing. Video training. \\
\hline 6 & Creation & $\begin{array}{l}\text { Creating algorithms for working with different types of } \\
\text { consumers (visitor, observer, client, supporter). }\end{array}$ \\
\hline
\end{tabular}

Source: Own research.

Let us take another problem, which is often requested by customers (such a request is especially put forward by the managers and owners of companies and enterprises): overcoming and preventing staff procrastination. We use the same design form as in the previous example, but the content has changed (see Table 6).

The topics and content of the pieces of training (Tables 5, 6) are different, while the overall structure is the same. It is a framework that can be filled with different content. We deliberately applied the same set of mental actions to demonstrate the methodological capacity of the taxonomy ideas in adult learning. 
Table 6.

Training design for overcoming a tendency to procrastinate by a pharmacy chain staff.

\begin{tabular}{c|c|l}
\hline & Stage & \multicolumn{1}{c}{ Content } \\
\hline 1 & Reproduction & $\begin{array}{l}\text { Discussion "Physical and Psychological Time." } \\
\text { Mini-lecture "Features of human perception of time." }\end{array}$ \\
\hline 2 & Understanding & $\begin{array}{l}\text { Participants' introspection: how often do I manage/fail to } \\
\text { do something in time? } \\
\text { Tests for procrastination propensity and time perspective } \\
\text { concept. }\end{array}$ \\
\hline 3 & Application & $\begin{array}{l}\text { Exercises: Training the ability to determine time without a } \\
\text { clock. Schedule of things to be done. Ranking of tasks. }\end{array}$ \\
\hline 4 & Analysis & $\begin{array}{l}\text { Case studies. How much time does each client need? How } \\
\text { can I prevent unproductive waste of time when working } \\
\text { with a client? }\end{array}$ \\
\hline 5 & Evaluation & $\begin{array}{l}\text { Role playing. What exactly do people have to control: time } \\
\text { or their attitude to it? }\end{array}$ \\
\hline 6 & Creation & $\begin{array}{l}\text { Creating a goal with a breakdown into stages of its } \\
\text { implementation. Developing long-term and short-term } \\
\text { plans and means of monitoring their implementation. }\end{array}$ \\
\hline
\end{tabular}

Source: Own research.

\section{CONCLUSION}

Summing up, B. Bloom's taxonomy and its modifications can be applied as a means of structuring adult learning. They should be used in interactive group work since they allow achieving educational objectives that correspond to different levels of learning activity, and introducing an element of the game that activates the affective sphere, reduces stress and tension, which is often associated with a sense of incompetence in adults. B. Bloom's taxonomy is a tool for designing both exercises and entire programs for adult learning. The levels of cognitive activity highlighted by B. Bloom can form the basis for group training on various topics. Depending on the purpose of the training and the required formation of certain competencies in its participants, various sets of mental operations can be used as a structural framework for the training design. This gives the training developers ample opportunities, but at the same time, structures work and, allows building a clear logical sequence of training activities.

\section{RESEARCH PROSPECTS}

The prospects of the study are as follows: to empirically explore the specifics of training programs based on B. Bloom's taxonomy, taking into account the main issues (subject areas) to adapt these programs as efficiently as possible to the socio-psychological characteristics of adult learners, while taking into account the latest approaches and trends in the field of mindset training. 


\section{REFERENCES}

[1] Anderson, L., \& Krathwohl, D. R. (2001). A Taxonomy for Learning, Teaching and Assessing: A revision of Bloom's Taxonomy of Educational Objectives. New York: Longman.

[2] Baranovska, L. V., \& Baranovsky, M. М. (2014). Концептуальний аспект навчання дорослих у системі вищої освіти України [Conceptual aspect of the adult education in the Ukrainian system of higher education]. Proceedings of the National Aviation University. Series: Pedagogy, Psychology, 5 (1), 14-19.

[3] Bloom, B. S. (1984). Taxonomy of educational objectives: The classification of educational goals. New York: Longman.

[4] Bloom, B. S., \& Krathwohl, D. R. (1956). Taxonomy of Educational Objectives: The Classification of Educational Goals, by a committee of college and university examiners. Handbook I: Cognitive Domain. New York: Longmans, Green.

[5] Carrington, A. (2015). The Padagogy Wheel...it's a Bloomin' Better Way to Teach. Retrieved May 15, 2020 from https://designingoutcomes.com/the-padagogy-wheel-its-a-bloomin -better-way-to-teach/

[6] Churches, A. (2008). Bloom's Digital Taxonomy. Retrieved May 15, 2020 from https://www. researchgate.net/publication/228381038_Bloom's_Digital_Taxonomy

[7] Fink, L. D. (2003). Creating Significant Learning Experiences: An Integrated Approach to Designing College Courses. San Francisco: Jossey Bass.

[8] Harris, G. L. (2013). Incorporating Adult Learning Methods and Project Based Learning in Laboratory Metrology Courses. In Proceedings of $120^{\text {th }}$ ASEE Annual Conference \& Exposition of the American Society for Engineering Education. Retrieved May 15, 2020 from https://tsapps.nist.gov/publication/get_pdf.cfm?pub_id=913716

[9] Harrow, A. J. (1972). A taxonomy of the psychomotor domain: A guide for developing behavioral objectives. New York: David McKay.

[10] Krathwohl, D. R. (2002). A Revision of Bloom's Taxonomy: An Overview. Theory Into Practice, 41:4, 212-218. Retrieved May 15, 2020 from https://doi.org/10.1207/s15430421tip4104_2

[11] Marzano, R. (2001). The New Taxonomy of Educational Objectives. Thousand Oaks: Corwin Press.

[12] O'Neill, G., \& Murphy, F. (2010). Assessment. Guide to Taxonomies of learning. Retrieved May 15, 2020 from http://www.ucd.ie/t4cms/ucdtla0034.pdf

[13] Podopryhora N. (2016). Таксономічний підхід до формування фахової компетентності майбутніх учителів і викладачів фізики в процесі навчання теоретичної фізики [Taxonomical approach to the forming of professional competence of future teachers of physics in the process of teaching theoretical physics]. Scientific notes. Series: Problems of Methods of Physical-Mathematical and Technological Education, 10 (2), 77-81.

[14]Samoylenko, O., \& Ivashchenko, M. (2017). Розвиток дистанційного навчання у педагогічній теорії та практиці: аналіз зарубіжних досліджень [Development of distance education in pedagigal theory and practice: An overview of foreign studies]. Theory and methods of educational management, 1 (19), 1-15.

[15] Sverdlova, I. (2015). Дидактичні основи управління когнітивними навичками учнів [Didactic basics of controlling students' cognitive skills]. Scientific Bulletin Melitopol State Pedagogical University. Series: Pedagogy, 2 (15), 82-88.

[16] Tsvyak, L. (2014). Психолого-педагогічні умови ефективного навчання дорослих іноземної мови [Psychological and pedagogical conditions for effective foreign language learning of adults]. Scientific Bulletin of UzhNU. Pedagogy. Social Work, 30, 178-180.

[17] UNESCO Recommendation on Adult Learning and Education (2015). Final Report of the Director General containing a Draft Recommendation on Adult Learning and Education. Retrieved May 15, 2020 from https:/ / unesdoc.unesco.org/ark:/48223/pf0000245179 